\title{
Conservation Agriculture practices reduce the global warming potential of rainfed low $\mathrm{N}$ input semi-arid agriculture
}

\author{
Angela Tellez-Rio , Antonio Vallejo , Sonia García-Marco , Diana Martin-Lammerding , \\ Jose Luis Tenorio , Robert Martin Rees , Guillermo Guardia
}

\begin{abstract}
A B S T R A C T
Conservation tillage and crop rotations improve soil quality. However, the impact of these practices on greenhouse gas (GHG) emissions and crop yields is not well defined, particularly in dry climates. A rainfed 2-year field-experiment was conducted to evaluate the effect of three long-term (17-18 years) tillage systems (Conventional Tillage (CT), Minimum Tillage (MT) and No Tillage (NT)) and two cropping systems (rotational wheat (Triticum aestivum L.) preceded by fallow, and wheat in monoculture), on nitrous oxide $\left(\mathrm{N}_{2} \mathrm{O}\right)$ and methane $\left(\mathrm{CH}_{4}\right)$ emissions, during two field campaigns. Soil mineral $\mathrm{N}$, water-filled pore space, dissolved organic carbon (C) and grain yield were measured and yield-scaled $\mathrm{N}_{2} \mathrm{O}$ emissions, $\mathrm{N}$ surplus and Global Warming Potentials (GWP) were calculated. No tillage only decreased cumulative $\mathrm{N}_{2} \mathrm{O}$ losses (compared to MT/CT) during campaign 1 (the driest campaign with least fertilizer $\mathrm{N}$ input), while tillage did not affect $\mathrm{CH}_{4}$ oxidation. The GWP demonstrated that the enhancement of $\mathrm{C}$ stocks under $\mathrm{NT}$ caused this tillage management to decrease overall $\mathrm{CO}_{2}$ equivalent emissions. Monoculture increased $\mathrm{N}_{2} \mathrm{O}$ fluxes during campaign 2 (normal year and conventional $\mathrm{N}$ input) and decreased $\mathrm{CH}_{4}$ uptake, as opposed to rotational wheat. Conversely, wheat in monoculture tended to increase soil organic $\mathrm{C}$ stocks and therefore resulted in a lower GWP, but differences were not statistically significant. Grain yields were strongly influenced by climatic variability. The NT and CT treatments yielded most during the dry and the normal campaign, and the yield-scaled $\mathrm{N}_{2} \mathrm{O}$ emissions followed the same tendency. Minimum tillage was not an adequate tillage management considering the GWP and the yield-scaled $\mathrm{N}_{2} \mathrm{O}$ emissions (which were $39 \%$ lower in NT with respect to MT). Regarding the crop effect, wheat in rotation resulted in a $32 \%$ increase in grain yield and $31 \%$ mitigation of yield-scaled $\mathrm{N}_{2} \mathrm{O}$ emissions. Low cumulative $\mathrm{N}_{2} \mathrm{O}$ fluxes ( $<250 \mathrm{~g} \mathrm{~N}_{2} \mathrm{O}-\mathrm{N} \mathrm{ha}^{-1}$ campaign $^{-1}$ ) highlighted the relevance of soil organic $\mathrm{C}$ and $\mathrm{CO}_{2}$ emissions from inputs and operations in rainfed semi-arid cropping systems. This study suggests that NT and crop rotation can be recommended as good agricultural practices in order to establish an optimal balance between GHGs fluxes, GWP, yield-scaled $\mathrm{N}_{2} \mathrm{O}$ emissions and $\mathrm{N}$ surpluses.
\end{abstract}

\section{Introduction}

Agriculture contributes to $10-12 \%$ of the total global anthropogenic greenhouse gases (GHGs)(Stocker et al., 2013), through the release of nitrous oxide $\left(\mathrm{N}_{2} \mathrm{O}\right)$, carbon dioxide $\left(\mathrm{CO}_{2}\right)$ and methane $\left(\mathrm{CH}_{4}\right)$. The global warming potential (GWP), which is a concept that integrates the radiative properties of all GHGs, expressed as $\mathrm{CO}_{2}$ equivalents $\left(\mathrm{CO}_{2}\right.$-eq), is very dependent on $\mathrm{N}_{2} \mathrm{O}$ emissions from agricultural crop systems. This gas, which is a by-product of microbial processes of nitrification and denitrification, (Firestone and Davidson, 1989), is released from soils after nitrogen (N) application (through fertilizers, manures or crop residues). By contrast, in aerated soils $\mathrm{CH}_{4}$ uptake normally reduces GWP, because the amount of $\mathrm{CH}_{4}$ oxidized by methanotrophic microorganisms is normally higher than the amount produced by methanogenic microoganisms (Chan and Parkin, 2001). Additionally, agricultural practices that favour carbon (C) sequestration (Robertson et al., 2000) are also considered as valuable strategies to reduce the negative effect of GHG emissions associated with crop production. Therefore, agricultural management practices (e.g. tillage, fertiliza- 
tion and crop rotation) must integrate the reduction of soil GHG emissions and the increase of organic C content, while maintaining or enhancing crop yields to satisfy increasing global food demand.

Conservation agriculture, which involves crop rotations and reduced tillage (no tillage (NT) or minimum tillage (MT)), is currently common in Mediterranean climates due to its effects on preserving soil fertility and increasing the soil $\mathrm{C}$ sink (Kassam et al., 2012). These tillage practices often contribute to improve important abiotic parameters involved in the production and consumption of GHG from soils such as soil water content, aeration and soil organic C (SOC) (Martin-Lammerding et al., 2011; Plaza-Bonilla et al., 2014; García-Marco et al., 2016) compared to conventional tillage (CT). However, contradictory results on $\mathrm{N}_{2} \mathrm{O}$ and $\mathrm{CH}_{4}$ fluxes have been reported (i.e. Pelster et al., 2011; Dendooven et al., 2012; Ball et al., 1999; Yonemura et al., 2014) due to interaction of tillage with several factors, e.g. soil type, climatic conditions (which determine the prevalence of nitrification or denitrification), nitrogen $(\mathrm{N})$ fertilization rate, crop residues (type and management), and the duration of experiments (van Kessel et al., 2013).

The effect of crop rotations on GHG emissions is variable depending on rainfed/irrigated conditions, composition and management of previous crop residues (Malhi and Lemke, 2007), and mineral $\mathrm{N}$ remaining in soil from previous cropping phases. Cereal residues (high C:N ratio) can promote soil $\mathrm{N}$ immobilization when they are applied without an additional source of mineral N, consequently leading to a temporary reduction of $\mathrm{N}_{2} \mathrm{O}$ fluxes (Huang et al., 2004). However, other authors (Sarkodie-Addo et al., 2003) have observed an enhancement of denitrification losses when a mineral source is added together with high C: $\mathrm{N}$ ratio residues, providing an energy supply for denitrifying microorganisms. Addition of $\mathrm{N}$ fertiliser may also inhibit $\mathrm{CH}_{4}$ uptake due to the interference of enzyme activity responsible for $\mathrm{CH}_{4}$ oxidation $\left(\mathrm{CH}_{4}\right.$ monooxygenase) with $\mathrm{NH}_{3}$ monooxygenase (Dunfield and Knowles, 1995), depending on $\mathrm{N}$ rate (Aronson and Helliker, 2010). Different quantities of crop residue are added to the soil under rotational wheat and wheat in monoculture systems, which can affect net $\mathrm{N}_{2} \mathrm{O}$ and $\mathrm{CH}_{4}$ production due to changes in soil $\mathrm{C}$ and $\mathrm{N}$ availability.

The influence of tillage and crop rotation on the stocks of SOC has been previously assessed, showing promising but contrasting results depending on management (e.g. type and duration of rotation) and experimental (e.g. depth, number of years since the beginning of the experiment) factors (Baker et al., 2007; Álvaro-Fuentes et al., 2014; Triberti et al., 2016). Thus, to identify whether conservation tillage practices (MT/NT and crop rotation) can mitigate both soil GHG emissions and net GWP is still unclear, particularly in semi-arid areas where the weight of direct $\mathrm{N}_{2} \mathrm{O}$ losses is expected to be lower.

In rainfed semi-arid cropping systems, characterized by a high variability in the total amount and distribution of rainfall, low $\mathrm{N}$ input systems are being promoted in order to match $\mathrm{N}$ input to the expected $\mathrm{N}$ uptake by crops (Kimani et al., 2003; Tellez-Rio et al., 2015), which may reduce the $\mathrm{N}$ surplus and also $\mathrm{N}$ losses (van Groenigen et al., 2010). Therefore, combining Conservation Agriculture practices with adjusted $\mathrm{N}$-input is expected to provide an optimum balance between GWP and crop yields in semi-arid agro-ecosystems. In this context, the main objective of this study was to evaluate the effect of three long-term tillage systems (CT, MT and NT) and two cropping systems (wheat in monoculture and wheat in a 4-year rotation with fallow as preceding crop) on $\mathrm{N}_{2} \mathrm{O}$ and $\mathrm{CH}_{4}$ emissions over two campaigns. Additionally, crop yield, yield-scaled $\mathrm{N}_{2} \mathrm{O}$ losses (YSNE) and GWP were evaluated. We hypothesized that: (1) considering climatic conditions of this experiment and the low $\mathrm{N}$ input, low $\mathrm{N}_{2} \mathrm{O}$ emissions would be expected in all treatments; (2) emissions of $\mathrm{N}_{2} \mathrm{O}$ and $\mathrm{CH}_{4}$ in winter wheat in monoculture could be higher than in the rotational winter wheat, because of a combined effect of previous crop residues and N fertilizer application; and (3) NT would reduce net GWP as a result of the reduction of $\mathrm{CO}_{2}$-eq emissions from farm operations and the increase of C stocks (Aguilera et al., 2013a).

\section{Materials and methods}

\subsection{Site characteristics}

A two-year study was carried out at "La Canaleja" Field Station $\left(40^{\circ} 32^{\prime} \mathrm{N}, 3^{\circ} 20^{\prime} \mathrm{W}, 600 \mathrm{~m}\right)$, in Alcalá de Henares (Madrid, Spain), where a long-term tillage experiment began in 1994. Tillage systems and crop rotations including legumes and fallow have been assessed since that date. The soil was a sandy-loam Calcic Haploxeralf (Soil Survey Staff, 2010). The main physicochemical properties of the top soil layer $(0-15 \mathrm{~cm})$ were: sand, $50.8 \%$; silt, $37.7 \%$; clay, $11.5 \% ; \mathrm{CaCO}_{3}, 41.6 \mathrm{~g} \mathrm{~kg}^{-1} ; \mathrm{pH}_{\mathrm{H} 2 \mathrm{O}}, 7.9$ and $\mathrm{EC}, 121.3 \mu \mathrm{S} \mathrm{cm}^{-1}$. The site has a semiarid Mediterranean climate with dry summers. The 1994-2013 mean annual temperature and rainfall for this area were $13.5^{\circ} \mathrm{C}$ and $402.7 \mathrm{~mm}$, respectively.

\subsection{Experimental design and management}

The experiment was conducted from October 2011 to October 2013. The experimental design was a three-replicated split plot, divided into three main plots assigned to the three tillage systems (NT, MT and CT) in a randomized complete block design (Guardia et al., 2016). Each of the main plots were further divided into five subplots $(10 \times 25 \mathrm{~m})$ assigned in a completely randomized design to the phases of an annual crop rotation, involving fallowwheat (Triticum aestivum L, var. Marius)-vetch (Vicia sativa L. var. Senda)-barley (Hordeum vulgare L. var. Kika), and also wheat in monoculture. In this study, we evaluated the effect of the three tillage systems mentioned above (tillage factor) and two cropping systems (cropping factor): wheat in rotation and wheat in monoculture; during two campaigns with different climatic (i.e. rainfall amount) and management conditions (i.e. rate of $\mathrm{N}$ fertilizer at dressing) (campaign factor): 2011/12 (campaign 1) and $2012 / 13$ (campaign 2), resulting in eighteen subplots ( 3 plots $\times 2$ subplots $\times 3$ replicate blocks).

Moldboard (20 cm depth) and chisel ploughs (15 cm depth) were used in autumn (early-November 2011 and late-October 2012, for campaign 1 and 2, respectively) in CT and MT plots, respectively. Then, a cultivator pass was carried out for both tillage systems. Thus, crop residues were almost completely incorporated into the soil in CT, whereas under MT the previous season's crop residues covered approximately $30 \%$ of the plot surface. No tillage involved direct drilling and spraying with glyphosate (at a rate of $2 \mathrm{~L} \mathrm{ha}^{-1}$ of Sting Monsanto ${ }^{*}$ ) for weed control, and previous season's crop residues were retained on the soil surface. Different types of crop residues were applied to the soil in the rotation treatment, depending on the phase of the rotation. Since wheat was preceded by fallow, the relatively small amount of biomass generated during that phase was left or incorporated into the soil surface of the following crop, winter wheat. By contrast, in wheat in monoculture, straw residue provided a greater $\mathrm{N}$ and $\mathrm{C}$ input ( $235 \mathrm{Mg} \mathrm{Cha}^{-1} ; 20 \mathrm{~kg} \mathrm{~N} \mathrm{ha}^{-1}$ ) to the following crop of wheat. Rotational and monoculture wheat were sown on 26th November 2011 and 14th November 2012 in campaigns 1 and 2, respectively, with $210 \mathrm{~kg} \mathrm{seed} \mathrm{ha}^{-1}$. Fertilizer was applied at seeding $\left(16 \mathrm{~kg} \mathrm{~N} \mathrm{ha}^{-1}\right.$ as NPK, 8-24-8) in both campaigns and at dressing as ammonium nitrate $\left(\mathrm{NH}_{4} \mathrm{NO}_{3}, 27-0-0\right)$ on 22nd March 2012 and 11th March 2013. The $\mathrm{N}$ fertilization rate at dressing was calculated by taking into account the expected crop yield and soil mineral $\mathrm{N}$ content two weeks before fertilizer application (February). There was a higher than average nitrate $\left(\mathrm{NO}_{3}{ }^{-}-\mathrm{N}\right)$ content in the $0-15 \mathrm{~cm}$ soil 
at dressing fertilization in campaign $1\left(27 \mathrm{mg} \mathrm{NO}_{3}{ }^{-}-\mathrm{N} \mathrm{kg}^{-1}\right)$ than in campaign $2\left(5.6 \mathrm{mg} \mathrm{NO}_{3}{ }^{-}{ }^{-} \mathrm{N} \mathrm{kg}^{-1}\right)$, which resulted in different $\mathrm{N}$ rates in campaign $1\left(11 \mathrm{~kg} \mathrm{Nha}^{-1}\right)$ and $2\left(54 \mathrm{~kg} \mathrm{Nha}^{-1}\right)$. All treatments received post-emergency herbicide treatments (HerbimurDoble ${ }^{8}$ ) at a rate of $1.6 \mathrm{~L} \mathrm{ha}^{-1}$ for both campaigns. Wheat was harvested on 10th June 2012 and 18th June 2013, for campaign 1 and 2 , respectively.

\subsection{GHG emissions sampling and analyzing}

Fluxes of $\mathrm{N}_{2} \mathrm{O}$ and $\mathrm{CH}_{4}$ were measured from October 2011 to October 2013, using the static chamber technique as described in Guardia et al. (2016). One chamber (diameter $35.6 \mathrm{~cm}$, height $19.3 \mathrm{~cm}$ ) was placed in each subplot and closed for $1 \mathrm{~h}$. GHGs were sampled three times per week during the first and second week, then twice per week during the first month after fertilization events or during rainfall periods and then, every week or every two weeks until the end of the cropping period. After harvest, one gas sample was taken each month or after rainfall events. To minimize any effects of diurnal variation in emissions, samples were taken at the same time of day (10-12 a.m.).

Gas samples $(20 \mathrm{~mL})$ were taken at 0,30 and $60 \mathrm{~min}$ to test the linearity of gas accumulation in each chamber. Samples were analyzed by gas chromatography using a HP-6890 gas chromatograph equipped with a ${ }^{63} \mathrm{Ni}$ electron-capture detector (Micro-ECD) and a flame ionization detector (FID) to analyze $\mathrm{N}_{2} \mathrm{O}$ and $\mathrm{CH}_{4}$, respectively. More details about the analysis and estimation of GHG fluxes can be found in Sanz-Cobena et al. (2014).

\subsection{Soil, crop analyses and meteorological data}

Composite soil samples were collected from each subplot at depths of $0-7.5 \mathrm{~cm}, 7.5-15 \mathrm{~cm}$ and $15-30 \mathrm{~cm}$, air-dried and sieved to determine SOC (Nelson and Sommers, 1996). Bulk density was determined (Grossman and Reinsch, 2002) each year (GómezPaccard et al., 2015; Guardia et al,, 2016) for the same soil depths as SOC. In order to relate gaseous emissions to soil properties, soil samples were collected from 0 to $15 \mathrm{~cm}$ depths during the growing season on almost all gas-sampling occasions. Dissolved organic $\mathrm{C}$ (DOC) and soil mineral $\mathrm{N}$ concentrations $\left(\mathrm{NH}_{4}{ }^{+}-\mathrm{N}\right.$ and $\left.\mathrm{NO}_{3}{ }^{-}-\mathrm{N}\right)$ were determined by extracting with deionized water or $\mathrm{KCl}(1 \mathrm{M})$, respectively. Afterwards, DOC and mineral $\mathrm{N}$ contents were analyzed using a total organic C analyser (multi N/C 3100 Analityk Jena) or a flow injection analyzer (FIAS 400 Perkin Elmer), respectively, as described in Guardia et al. (2016). The water-filled pore space (WFPS) was determined and calculated as explained in Tellez-Rio et al. (2015).

Hourly rainfall and air temperature data were obtained from a meteorological station located at the field site. Soil temperature was measured in each tillage system by inserting a temperature probe $15 \mathrm{~cm}$ into the soil. Mean hourly temperature data were stored on a data logger. Grain yield and above-ground biomass were measured by harvesting two randomly selected areas $\left(0.5 \times 0.5 \mathrm{~m}^{2}\right)$ from each subplot and total $\mathrm{N}$ determined (TruMac $\mathrm{CN}$ Leco elemental analyzer).

\subsection{YSNE, N surplus and GWP calculations}

Yield-scaled $\mathrm{N}_{2} \mathrm{O}$ emissions, expressed as $\mathrm{g} \mathrm{N}_{2} \mathrm{O}-\mathrm{N}$ per $\mathrm{kg}$ of $\mathrm{N}$ uptake, were calculated based on the approach described by van Groenigen et al. (2010), using total above-ground N uptake (wheat grain and straw). The $\mathrm{N}$ surplus was calculated as $\mathrm{N}$ fertilizer application minus above-ground N uptake (van Groenigen et al., 2010). The sink of SOC ( $\triangle S S^{\prime}$ ') in the top $30 \mathrm{~cm}$ of soil and $\mathrm{CO}_{2}$ emissions from fuel used in farm operations (e.g. tillage, herbicide and fertilizer application, seeding, harvest) and from manufacturing inputs (operation GHG emission + input GHG emission) were calculated as described by Guardia et al. (2016). The ' $\triangle$ SOC' component, as an indicator of the soil $\mathrm{C}$ balance, was calculated taking the difference in SOC stocks between M-CT (as the baseline, since it represents the conventional and traditional management in comparison to the evaluated Conservation Agriculture practices) and the other treatments. To avoid the bias associated with changes in bulk density, the comparison of $\mathrm{C}$ stocks was made on a fixed soil mass basis, as described in Ellert and Bettany (1995). Default values of GHG emissions derived from farm operations and manufacturing inputs have been reported by West and Marland (2002), Lal (2004) and Snyder et al. (2009).

\subsection{Statistical analysis}

Statistical analyses were carried out with Statgraphics Plus 5.1. Analyses of variance (two-way ANOVA) were performed for almost all variables in the experiment for both campaigns (except climatic ones). A three-way ANOVA was also carried out in order to assess the effect of each campaign and the possible interactions among factors (campaign, tillage and crop). The normality and variance uniformity of data were assessed by the Shapiro-Wilk test and Leveneís statistic, respectively, and log-transformed before analysis when necessary. Means were separated by Tukey's honest significance test at $P<0.05$. For non-normally distributed data (mean soil $\mathrm{NH}_{4}{ }^{+}$content and YSNE in campaign 1 in the three-way ANOVA), the Kruskal-Wallis test was used on non-transformed data to evaluate differences at $P<0.05$. Linear regression analyses were carried out to determine relationships between cumulative gas fluxes and soil parameters, with a $95 \%$ significance level.

\section{Results}

\subsection{Environmental conditions, soil $C$ and mineral $N$ contents}

Total rainfall was $194 \mathrm{~mm}$ in campaign 1 and $369 \mathrm{~mm}$ in campaign 2 (Fig. 1a), with a mean rainfall in the experimental area (1994-2013) of $365 \mathrm{~mm}$. The soil WFPS values (Fig. 1b) in NT treatments were often higher than those in CT or MT. For NT the number of days with WFPS above $50 \%$ was $25-48$ and 72-88 days in campaign 1 and 2, respectively; whereas those for CT were 10-15 and 25-35 days; and those for MT were 4-8 days in both campaigns.

Topsoil $\mathrm{NH}_{4}{ }^{+}$content (Fig. $2 \mathrm{a}$ and b) peaked after each fertilization event. Average $\mathrm{NH}_{4}{ }^{+}$values did not show significant differences between tillage and cropping systems, but were significantly smaller $(P<0.05)$ in campaign 1 than in campaign 2 . The soil $\mathrm{NO}_{3}{ }^{-}$content in the topsoil (Fig. $2 \mathrm{c}$ and d) also increased after fertilization events in both campaigns, and no differences between cropping systems or tillage treatments were reported, Despite lower $\mathrm{N}$ application rates, the average $\mathrm{NO}_{3}{ }^{-}$content was higher in campaign 1 than in campaign $2(P<0.05)$.

The DOC content of the topsoil $(0-15 \mathrm{~cm})$ is represented in Fig. 2e, f. The mean DOC content for NT (taking into account the whole crop period) was significantly higher than that for MT and CT ( 27 and $50 \%$ for campaign $1 ; 36$ and $42 \%$ for campaign 2 , respectively). No significant differences were found between cropping systems and campaigns. The SOC content in the upper soil layer was significantly increased after 17 years under NT, as opposed to MT and $C T$ (Table 1). The highest SOC concentrations in the $15-30 \mathrm{~cm}$ layer were observed in CT $(P<0.05)$, but the SOC stock of the three soil layers $(0-30 \mathrm{~cm})$ was significantly higher in the NT treatment. With regards to the cropping effect, wheat in monoculture also tended to increase $\mathrm{SOC}$ content compared with rotational wheat $(0.05<P<0.10)$. 

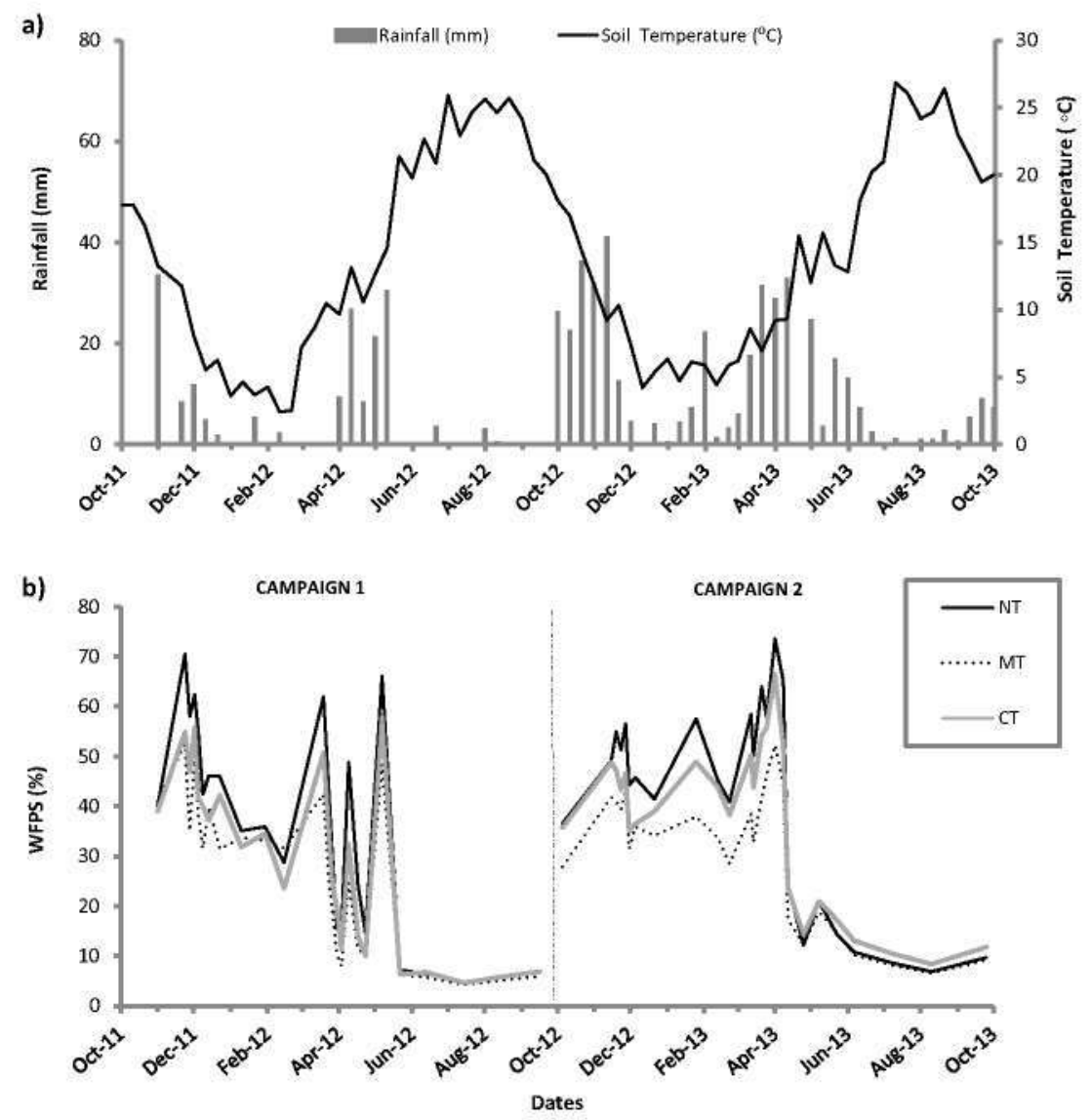

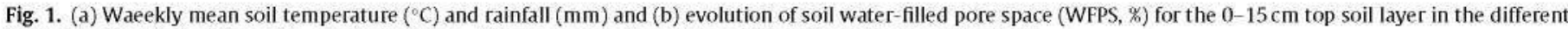
tillage treatments (no tillage, NT, minimum tillage, MT, and conventional tillage, CT) during both crop campaigns.

Table 1

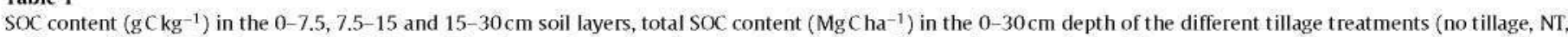
minimum tillage, MT, and conventional tillage, $\mathrm{CT}$ ) and cropping system (rotational wheat, W, and wheat in monoculture, M). .

\begin{tabular}{|c|c|c|c|c|}
\hline \multirow[b]{2}{*}{ Depth $(\mathrm{cm})$} & \multicolumn{3}{|c|}{$\operatorname{SOC}\left(\mathrm{g} \mathrm{kg}^{-1}\right)$} & \multirow{2}{*}{$\begin{array}{l}\text { Total SOC }\left(\mathrm{Mgha}^{-1}\right) \\
0-30\end{array}$} \\
\hline & $0-7.5$ & $7.5-15$ & $15-30$ & \\
\hline Tillage & $P=0.001$ & $P=0.516$ & $P=0.035$ & $P=0.033$ \\
\hline NT & $11.2 \mathrm{~b}$ & 5.8 & $4.6 \mathrm{a}$ & $28.8 b$ \\
\hline MT & $6.7 \mathrm{a}$ & 5.4 & $4,6 a$ & $22,9 a$ \\
\hline $\mathrm{CT}$ & $5.7 \mathrm{a}$ & 5.4 & $5.3 b$ & $22,9 a$ \\
\hline S.E. & 0.7 & 0,3 & 0,2 & 1.4 \\
\hline Crop & $P=0.186$ & $P=0.008$ & $P=0.117$ & $P=0,070$ \\
\hline W & 7.2 & $4.9 \mathrm{a}$ & 4.7 & 23.1 \\
\hline $\mathrm{M}$ & 8.5 & $6,1 b$ & 5,1 & 26,6 \\
\hline S.E. & 0.6 & 0.2 & 0.1 & 1.1 \\
\hline Tillage crop & $P=0.713$ & $P=0.130$ & $P=0.098$ & $P=0,308$ \\
\hline
\end{tabular}

Different letters within columns indicate significant differences by applying the Tukey's honest significance test at $P<0,05$. Standard Error (S.E.) is given for each effect.

\section{2. $\mathrm{N}_{2} \mathrm{O}$ and $\mathrm{CH}_{4}$ emissions}

Nitrous oxide fluxes (Fig. 3) ranged from -0.18 to $0.46 \mathrm{mg} \mathrm{N}_{2} \mathrm{O}$ $\mathrm{N} \mathrm{m}^{-2} \mathrm{~d}^{-1}$. Highest emissions were recorded after seeding and top-dressing fertilization, although negative $\mathrm{N}_{2} \mathrm{O}$ fluxes were measured on several occasions. With regards to cumulative emissions (Table 2), significant interactions of the campaign factor with both tillage (significant at $P<0.10$ ) and crop were reported. In campaign 1, cumulative $\mathrm{N}_{2} \mathrm{O}$ emissions were significantly lower for NT than those for MT and CT, while no significant crop effect or tillage* ${ }^{*}$ crop interactions were found. In campaign 2, higher cumulative $\mathrm{N}_{2} \mathrm{O}$ emissions $(P<0.05)$ were observed in the wheat in monoculture (with respect to rotational wheat), with no significant effect of tillage or the interaction of factors. Total cumulative $\mathrm{N}_{2} \mathrm{O}$ fluxes were greater $(P<0.05)$ in campaign 2 than in campaign 1 . The ratio of $\mathrm{N}_{2} \mathrm{O}-\mathrm{N}$ emitted per unit of mineral $\mathrm{N}$ applied was significantly greater $(P<0.05)$ during campaign $1(0.52 \%)$ than during campaign $2(0.28 \%)$.

Methane emissions ranged from -1.32 to $0.46 \mathrm{mg} \mathrm{CH}_{4}-$ $\mathrm{C} \mathrm{m}^{-2} \mathrm{~d}^{-1}$ (data not shown). In both campaigns, net $\mathrm{CH}_{4}$ oxidation (Table 2) was significantly lower in the wheat in monoculture than in rotational wheat, whereas no significant effect of tillage was reported $(P>0.05)$. In campaign 1 , a significant and negative correlation was found between $\mathrm{CH}_{4}$ fluxes and $\mathrm{NH}_{4}{ }^{+}-\mathrm{N}$ content $(P<0.05$, $\mathrm{n}=20, \mathrm{r}=-0.52$ ). Methane emissions correlated with WFPS content in both campaigns $(P<0.05, \mathrm{n}=20, \mathrm{r}=0.50)$. 

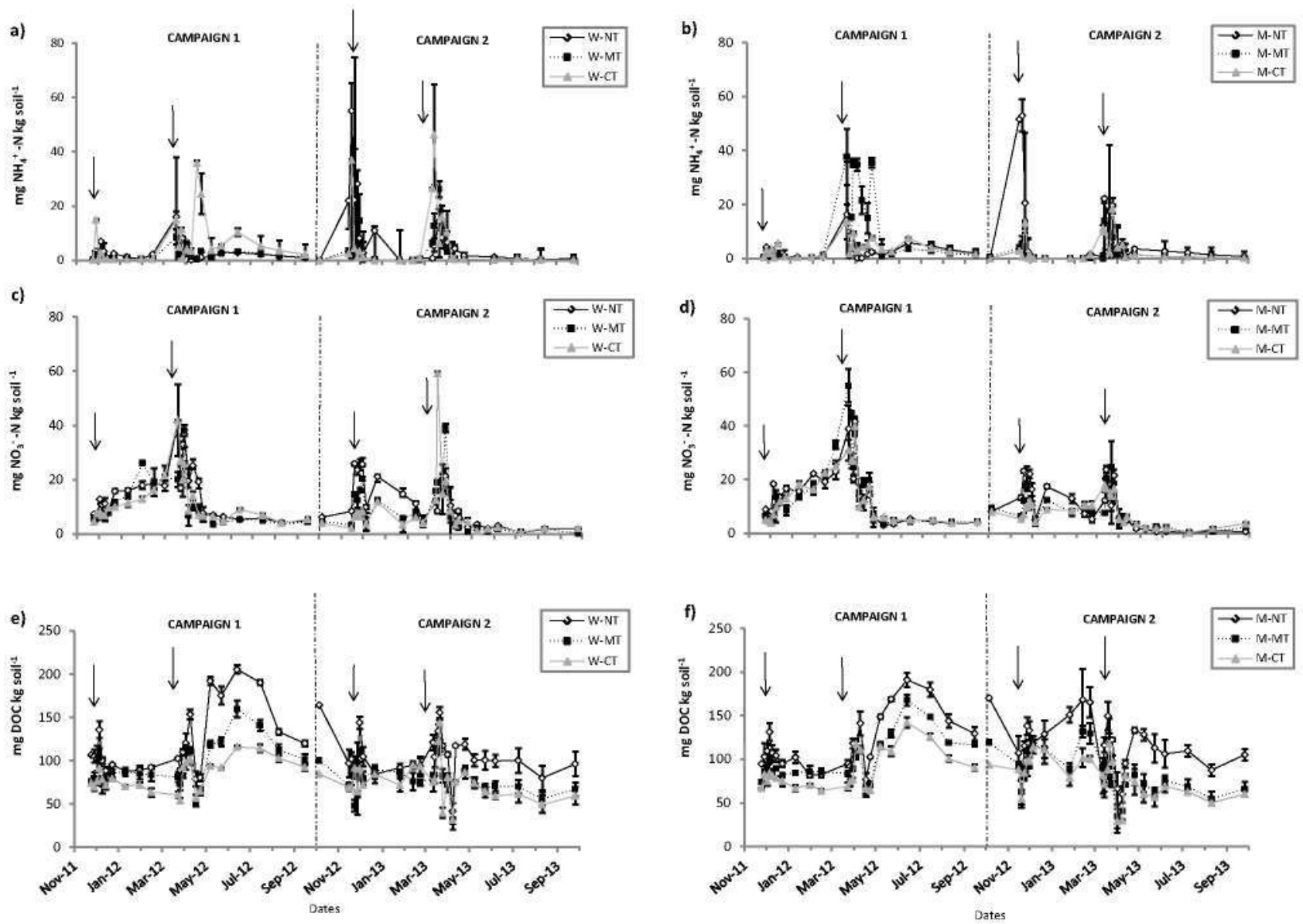

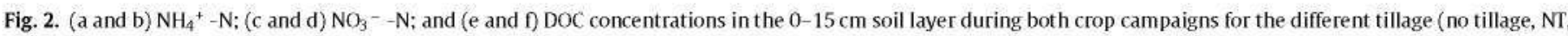

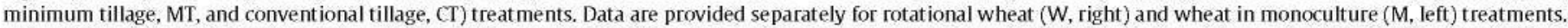
The arrows indicate the dates of application of synthetic N. Vertical lines indicate standard errors,

\subsection{Crop yield, YSNE and N surplus}

Grain yield (Table 2) was significantly higher in campaign 2 than in $1(P<0.001)$. Crop yield for both campaigns (three-way ANOVA), showed a significant interaction $(P<0.05)$ between campaign and tillage: NT tended to increase (compared with $\mathrm{CT}$ ) grain yield in the dry campaign 1 while the opposite tendency was observed in the normal campaign 2. On average, MT led to numerically (but not statistically) lower yields than NT and CT. Regarding cropping effect, grain yield in rotational wheat was significantly higher $(P<0.05)$ than that in wheat in monoculture.

In campaign 1 , YSNE were significantly lower $(P<0.05)$ for NT than those for MT and CT (Table 2), whereas no significant differences were observed for the crop effect. Across both campaigns, MT and wheat in monoculture significantly increased YSNE as opposed to NT and rotational wheat, respectively. However, a significant interaction of tillage with the campaign factor was observed, since NT and CT were the tillage treatments with most mitigated YSNE in campaign 1 and 2 , respectively. The values for $\mathrm{N}$ surplus were significantly lower $(P<0.05)$ in campaign 2 than campaign 1 (Table 2 ). There were no significant differences in $\mathrm{N}$ surplus values for the other effects (tillage, crop and interactions).

\subsection{Global warming potential}

The net GWP was significantly lower in NT than in MT and CT (Table 3). Wheat in monoculture tended to decrease the net
GWP as a result of higher SOC contents, but differences were not statistically significant at $95 \%$ significance level. The GHG-GWP (soil $\mathrm{N}_{2} \mathrm{O}$ and $\mathrm{CH}_{4}$ fluxes) component was significantly affected by tillage and crop factors, since CT and wheat in monoculture significantly increased $\mathrm{CO}_{2}$-eq emissions compared with NT and rotational wheat, respectively. The GWP was higher during campaign 2 as a result of higher $\mathrm{N}$ fertilizer input (Fig. 4). The ' $\triangle \mathrm{SOC}$ ' component was generally lower in $\mathrm{W}$ than in the conventional M-CT, except under NT.

\section{Discussion}

\subsection{Effect of campaign, tillage and crop systems on $\mathrm{N}_{2} \mathrm{O}$ emissions}

The main factor affecting $\mathrm{N}_{2} \mathrm{O}$ emissions in this experiment was $\mathrm{N}$ input (from chemical fertilizer and crop residues), which was very dependent on the campaign and the soil moisture, which in turn was influenced by rainfall amount and distribution. In this context, $\mathrm{N}_{2} \mathrm{O}$ fluxes were significantly higher in campaign 2 (with the highest $\mathrm{N}$ input and rainfall) (Table 2). Due to the complexity of factors and processes affecting the release of $\mathrm{N}_{2} \mathrm{O}$ emissions, the effect of tillage and crop factors was not consistent throughout both campaigns, so that the interactions need to be analyzed in detail. Contrary to our hypothesis, tillage systems did not have any significant effect on $\mathrm{N}_{2} \mathrm{O}$ emissions when the data from both campaigns are considered (Table 2). Our results were in agreement with those of Tellez-Rio et al. (2015) and Guardia et al. (2016) under simi- 
a)
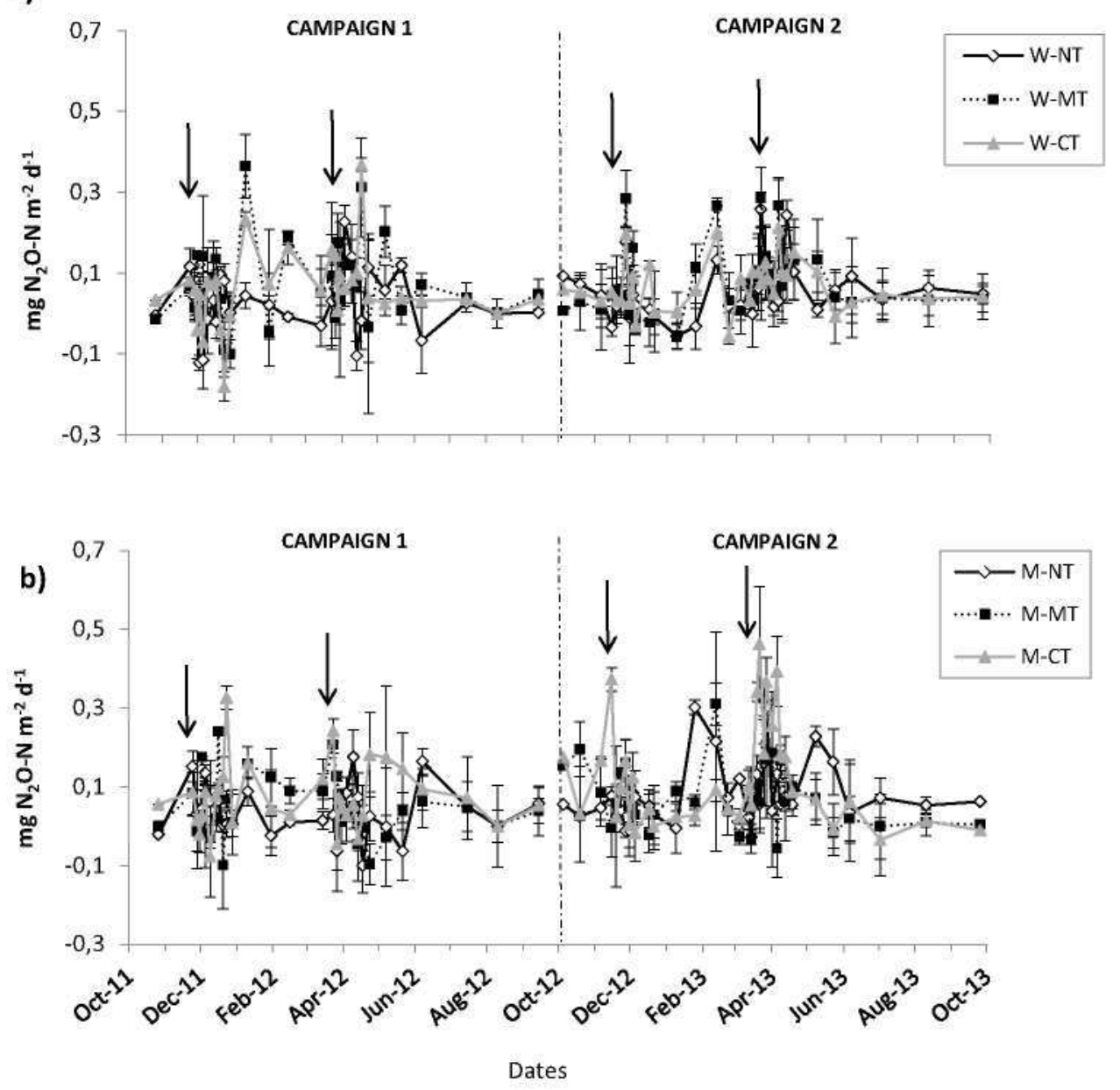

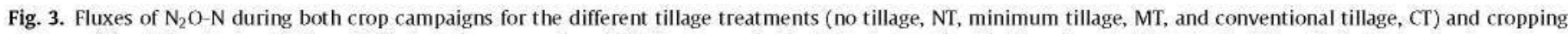
systems: (a) rotational wheat (W), and (b) wheat in monoculture (M). The arrows indicate the dates of application of synthetic N. Vertical lines indicate standard errors.

lar climatic conditions. As observed for tillage, the crop effect did not influence $\mathrm{N}_{2} \mathrm{O}$ emissions across the 2 campaigns. These results could be explained by the similar rates of synthetic $\mathrm{N}$ which was applied to both cropping systems, although a significant interaction (Table 2) with the campaign effect (i.e. higher $\mathrm{N}_{2} \mathrm{O}$ losses in wheat in monoculture than in rotational wheat, but only in the second campaign) was observed. This interaction suggests that the effect of residues from previous crops can be comparable and even higher than that of synthetic fertilizers (Lenka and Lal, 2013), especially in calcareous soils and low $\mathrm{N}$ input semi-arid cropping systems. Additionally, the effect of tillage was not consistent in the two campaigns, since $\mathrm{NT}$ significantly reduced $\mathrm{N}_{2} \mathrm{O}$ losses during campaign 1 but not during campaign 2 (normal precipitation and $\mathrm{N}$ input) compared with MT or CT. That caused the tillage*campaign interaction to be significant at $10 \%$ significance level.

The meta-analysis of van Kessel et al. (2013) reported a significant mitigation of $\mathrm{N}_{2} \mathrm{O}$ emissions under $\mathrm{NT}$ in dry climates and long-term (>10 years) studies. Lower emissions following longterm adoption of NT were explained as a result of the improvements of SOC content and porosity, thus reducing the formation of anaerobic microsites (Six et al., 2004). These lower emissions were generally observed under NT in our study for both campaigns in the rotational wheat system and also for monoculture wheat in campaign 1, supporting the results of van Kessel et al. (2013). Conversely, the results of monoculture in campaign 2 did not agree with this study, because relatively high $\mathrm{N}_{2} \mathrm{O}$ fluxes, particularly after dressing fertilization were observed in the NT plots (Fig. 5). There- fore, we hypothesized that the influence of the climatic conditions (particularly rainfall) and tillage (incorporating/leaving the residue on surface) on the mineralization of previous crop residues (whose amount was different between cropping systems, as explained in Section 2.2) drove the $\mathrm{N}_{2} \mathrm{O}$ emission pattern in our experiment. In the case of rotational wheat, an important part of crop residue was presumably mineralized during fallow period (the previous year of

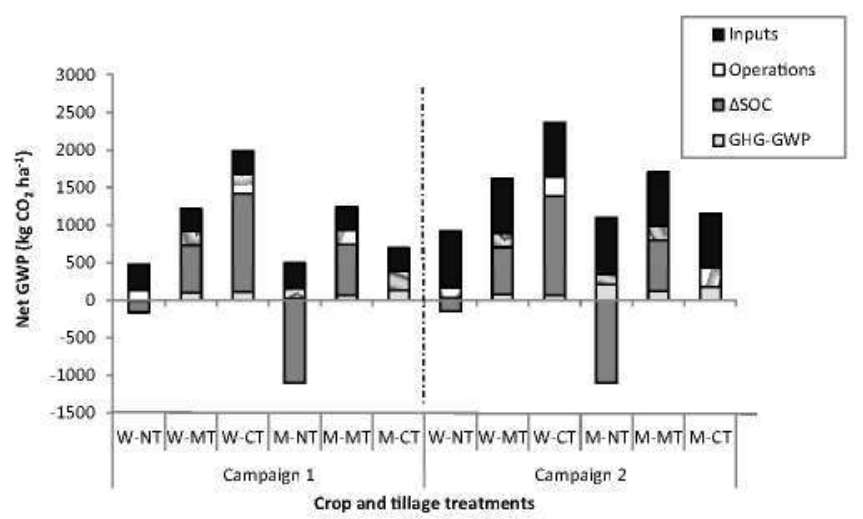

Fig. 4. Relative contribution of each GHG source/sinkto Net Global Warming Potential (GWP) in each tillage (no tillage, NT, minimum tillage, MT, and conventional tillage, CT) and cropping treatment (rotational wheat, W, and wheat in monoculture, M) during both crop campaigns. 


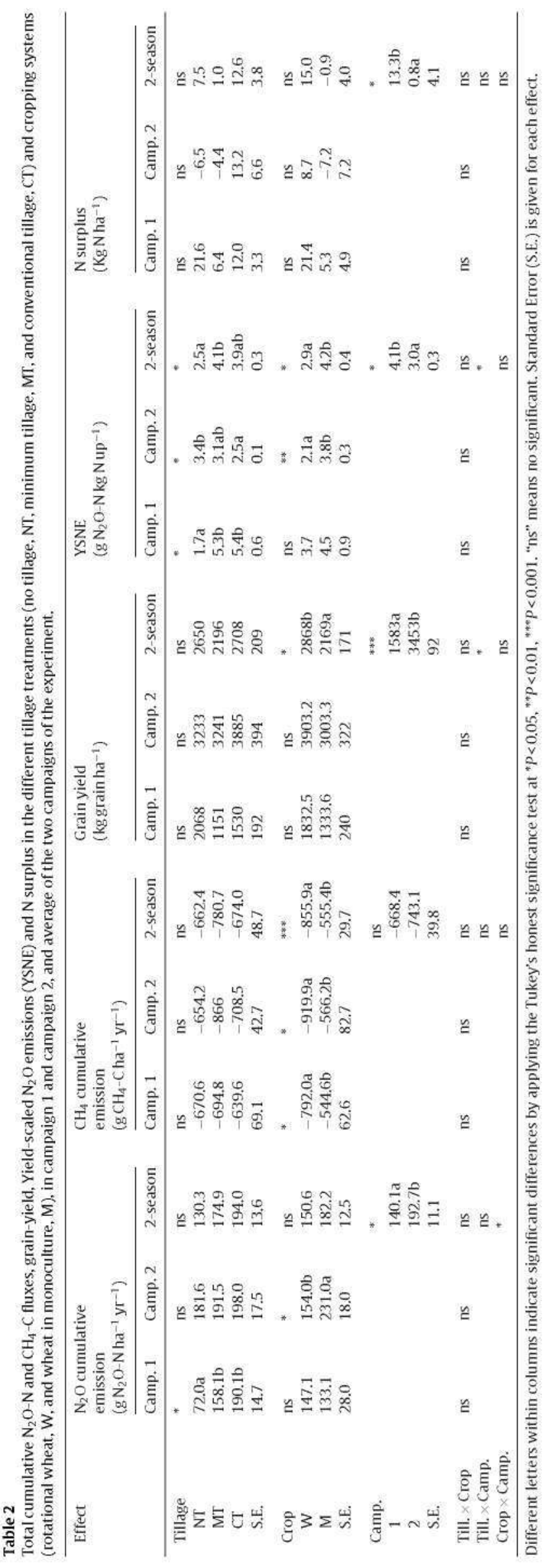

Table 3

Estimated Global Warming Potential (GWP, $\mathrm{kg} \mathrm{CO}_{2} \mathrm{eq} \mathrm{ha}^{-1} \mathrm{yr}^{-1}$ ) for the different tillage treatments (no tillage, NT, minimum tillage, MT, and conventional tillage, $\mathrm{CT}$ ) and cropping systems (rotational wheat, $\mathrm{W}$, and wheat in monoculture, $\mathrm{M}$ ).

\begin{tabular}{llll}
\hline \multicolumn{4}{l}{ Global Warming Potential (GWP, $\left.\mathrm{kg} \mathrm{CO}_{2} \mathrm{eq} \mathrm{ha}^{-1} \mathrm{yr}^{-1}\right)$} \\
\hline Effect & GHG-GWP & $\Delta \mathrm{SOC}^{2}$ & Net GWP \\
\hline Tillage & $P=0.077$ & $P=0.008$ & $P=0.010$ \\
NT & $58.6 \mathrm{a}$ & $-624.7 \mathrm{a}$ & $116.0 \mathrm{a}$ \\
MT & $89.8 \mathrm{ab}$ & $652.0 \mathrm{~b}$ & $1444.8 \mathrm{~b}$ \\
CT & $119.4 \mathrm{~b}$ & $658.2 \mathrm{~b}$ & $1546.7 \mathrm{~b}$ \\
S.E. & 17.0 & 310.0 & 303.0 \\
Crop & $P=0.009$ & $P=0.060$ & $P=0.078$ \\
W & $58.4 \mathrm{a}$ & 600.8 & 1377.3 \\
M & $120.1 \mathrm{~b}$ & -143.8 & 694.4 \\
S.E. & 13.9 & 253.1 & 247.4 \\
Campaign & $P=0.047$ & - & $P=0.189$ \\
1 & $67.5 \mathrm{a}$ & - & 806.1 \\
2 & $111.0 \mathrm{~b}$ & - & 1265.3 \\
S.E. & 13.9 & - & 247.4 \\
Tillage $\times$ crop & $P=0.181$ & $P=0.332$ & $P=0.332$ \\
Tillage $\times$ campaign & $P=0.069$ & - & $P=0.988$ \\
Crop $\times$ campaign & $P=0.026$ & - & $P=0.883$ \\
\hline
\end{tabular}

Different letters within columns indicate significant differences by applying the Tukey's honest significance test at $P<0,05$. Standard Error (S.E.) is given for each effect.

${ }^{1}$ Sum of $\mathrm{CO}_{2}$ equivalents from $\mathrm{N}_{2} \mathrm{O}$ and $\mathrm{CH}_{4}$ emissions, considering a 100 -year horizon (IPCC, 2014).

$2 \mathrm{CO}_{2}$ equivalents from the accumulation of soil organic $\mathrm{C}$ (SOC), calculated taking the difference in SOC stocks between M-CT (as baseline) and the rest of tillage treatments, dividing it by the number of years since the experiment started (17) and considering the $\mathrm{CO}_{2} / \mathrm{C}$ molar ratio.

${ }_{3}$ Sum of $\mathrm{CO}_{2}$ equivalents from $\mathrm{N}_{2} \mathrm{O}$ and $\mathrm{CH}_{4}$ emissions, $\triangle \mathrm{SOC}$, operations and inputs.
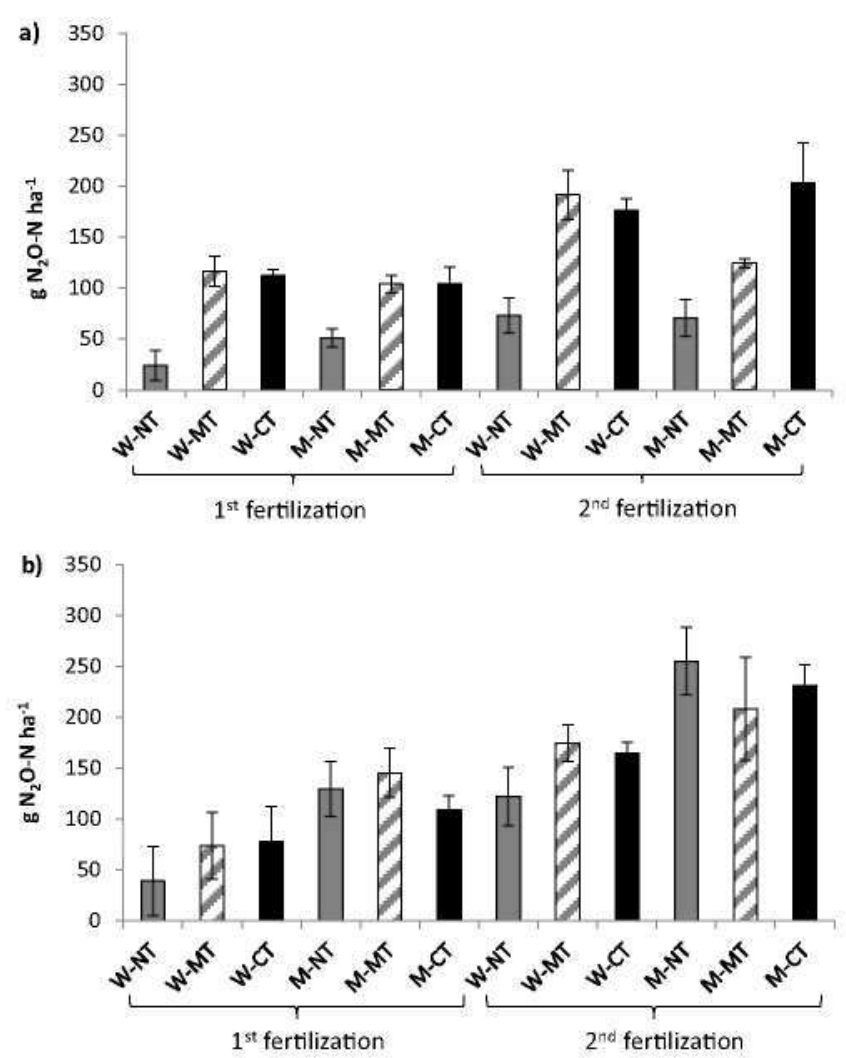

Fig. 5. Cumulative $\mathrm{N}_{2} \mathrm{O}-\mathrm{N}$ emissions in (a) campaign 1 and (b) campaign 2 for the different tillage (no tillage, NT, minimum tillage, MT, and conventional tillage, CT) and cropping (rotational wheat, $\mathrm{W}$, and wheat in monoculture, $\mathrm{M}$ ) treatments, from the beginning of the campaign to dressing fertilization (1st fertilization) and from dressing fertilization to the end of the campaign (2nd fertilization). Vertical lines indicate standard errors. 
rotational wheat growing phase), so $\mathrm{N}_{2} \mathrm{O}$ fluxes may have been less dependent on the interaction of crop residue and mineral fertilizer than in continuous cropping of the winter wheat. However, in campaign 1, differences in $\mathrm{N}_{2} \mathrm{O}$ emissions due to crop residue inputs were not observed between cropping systems. We hypothesized that the low rainfall amounts in campaign 1 limited soil water availability, particularly soil moisture content, which was not enough to promote intensive $\mathrm{N}$ mineralization and crop residues turnover, hence not stimulating $\mathrm{N}_{2} \mathrm{O}$ production (Mutegi et al., 2010). The number of days with a WFPS above $50 \%$, which has been suggested as a threshold for highest $\mathrm{N}_{2} \mathrm{O}$ losses (Linn and Doran, 1984; Li et al., 2016) was lower in campaign 1 (from 4 to 48 days) than in campaign 2 (from 7 to 88 days), depending on tillage system, supporting our findings.

By contrast, the $\mathrm{N}_{2} \mathrm{O}$ emissions during campaign 2 were higher in wheat in monoculture than in rotational wheat. This effect could be a result of better environmental conditions for the mineralization of crop residues from the previous year (Chen et al., 2013). In monoculture wheat, a combination of residue inputs with a high C:N ratio (mean C:N ratio of 160.3 ) and mineral $\mathrm{N}$ fertilizer, both at seeding and dressing, may have stimulated denitrification losses from mineral $\mathrm{N}$ added to soil ( $\mathrm{Li}$ et al., 2016), as residues provide an energy supply for denitrifying microorganisms (Sarkodie-Addo et al., 2003; Sanz-Cobena et al., 2014). This effect was particularly noticeable after dressing fertilization in the campaign 2, increasing fluxes in the monoculture wheat-NT treatment and changing the trend observed in the first campaign and the beginning of the second (Fig. 5). In summary, we hypothesized that the slower mineralization of non-incorporated wheat residues in NT (with respect to $\mathrm{MT} / \mathrm{CT}$ ) favored the $\mathrm{N}_{2} \mathrm{O}$ release from the interaction of dressing synthetic $\mathrm{N}$ and the mineralization of wheat residues, during the season (spring) and the campaign (2, as opposed to the dry campaign 1) with more favorable conditions for mineralization (Abalos et al., 2013; Guardia et al., 2016).

\section{2. $\mathrm{CH}_{4}$ emissions}

In this long-term tillage study, cumulative emissions provided a net $\mathrm{CH}_{4}$ sink in all tillage and cropping systems (Table 2), as generally reported in agricultural soils under semiarid conditions (Snyder et al., 2009). The negative correlation found between soil $\mathrm{NH}_{4}{ }^{+}$content and $\mathrm{CH}_{4}$ fluxes $(P<0.05)$ in campaign 1 was in agreement with the meta-analysis of Aronson and Helliker (2010), which reported that low amounts of $\mathrm{N}\left(<100 \mathrm{~kg} \mathrm{ha}^{-1}\right.$, as those of our experiment) tend to stimulate methanotrophy, while larger rates are inhibitory.

Tillage systems did not produce significant differences in $\mathrm{CH}_{4}$ uptake in any campaign, which is consistent with results reported by Guardia et al. (2016) and Tellez-Rio et al. (2015), under semiarid Mediterranean conditions. However, some authors have suggested that the improvement of soil structure in NT, associated with increases in macroporosity and reduction of anaerobic microsites, can favour $\mathrm{CH}_{4}$ consumption (Plaza-Bonilla et al., 2014). Our results may have been a consequence of similar topsoil porosity in all tillage systems and the low soil moisture content maintained during campaign 1 (particularly) and 2.

Greater $\mathrm{CH}_{4}$ oxidation $(P<0.05)$ was found in rotational wheat (preceded by fallow) than in wheat in monoculture in both campaigns. The incorporation of high $\mathrm{C}: \mathrm{N}$ crop residues has been reported to increase $\mathrm{CH}_{4}$ emissions (Le Mer and Roger, 2001), and that may have partially offset the $\mathrm{CH}_{4}$ oxidation in monoculture wheat subplots, where a higher amount of straw was retained/incorporated. This was also reported by Lenka and Lal (2013), who showed that $\mathrm{CH}_{4}$ uptake capacity was increased in bare soil when compared to treatments with residue amendment.

\subsection{Grain yield, YSNE and $N$ surplus}

Grain yield was affected by campaigns, which decreased almost $50 \%$ in the dry campaign 1 compared to campaign 2 , due to the low rainfalls measured in campaign 1 . The tillage* campaign interaction in wheat yields (see Section 3.3) showed that the most productive tillage system was dependent on climate and management conditions (Table 2). Controversy still exists about crop yield declines in NT, but CT overall leads to higher crop yields in experiments with high water and nutrient availability (Chatskikh and Olesen, 2007), whereas in semiarid agro-ecosystems, the reductions in water evaporation and the enhancement of water availability and soil fertility achieved with NT adoption can result in higher yields (De Vita et al., 2007; Morell et al., 2011; Plaza-Bonilla et al., 2014). These previous findings are in agreement with our results in the dry ( $<200 \mathrm{~mm}$ ) campaign 1 and the normal $(>300 \mathrm{~mm}$ ) campaign 2 , and with the meta-analysis of van Kessel et al. (2013) or Pittelkow et al. (2015). Considering the average 2-campaigns data, MT resulted in numerically but not statistically lower yield than those of CT or NT. The increased weed pressure in this tillage system (Armengot et al., 2015) was also observed in our experimental site, and could explain this tendency. With regards to crop effect, wheat in monoculture significantly reduced grain yield compared with rotational wheat, especially in campaign 2 . Our results confirm the positive effect of crop rotation on wheat yield under semi-arid conditions (López-Bellido and López-Bellido, 2001). Conversely, to elucidate the best management options for increasing farm returns, the whole rotation should be taken into account, since this type of rotation included a fallow (which may offset the increases in grain yields of the subsequent wheat phase) and a legume crop. In this sense, the possible cost abatement derived from incidences of pests (which are higher under continuous cropping of cereals) (SanzCobena et al., 2016) or the payments that legumes are liable to receive due to new EU mandatory policy (e.g. crop diversification or surfaces of ecological interest) need to be considered, although are outside of the boundaries of this study.

The YSNE from our study were in the lowest range of values reported by van Groenigen et al. (2010), as previously found in semi-arid areas (Tellez-Rio et al., 2015; Guardia et al., 2016). Since grain yield was not high (compared with other wheat cropping areas), these low YSNE were a result of small $\mathrm{N}_{2} \mathrm{O}$ losses, ranging from 0.07 to $0.23 \mathrm{~kg} \mathrm{~N}_{2} \mathrm{Oha}^{-1} \mathrm{yr}^{-1}$, compared to those (0.04-21.21 $\mathrm{kg} \mathrm{N}_{2} \mathrm{Oha}^{-1}$ ) for European arable sites (Rees et al., 2013). Besides the small $\mathrm{N}_{2} \mathrm{O}$ emissions due to the low $\mathrm{N}$ fertilization rates, the low ratio of $\mathrm{N}_{2} \mathrm{O}-\mathrm{N}$ emitted per unit of mineral $\mathrm{N}$ applied (see Section 3.2) confirms that the $\mathrm{N}_{2} \mathrm{O}$ emission factors of rainfed semi-arid areas are much lower than the IPCC default value (Aguilera et al., 2013b; Cayuela et al., 2016). In this type of agroecosystem, $\mathrm{N}_{2} \mathrm{O}$ emissions during winter are substantially limited by soil temperatures, while low WFPS is the main limiting factor for large $\mathrm{N}_{2} \mathrm{O}$ losses during spring (when most growth of winter crops occurs). Additionally, low SOC contents (Ussiri and Lal, 2012) and high soil pH conditions (Baggs et al., 2010), as was the case for our experimental site, may have also contributed to low $\mathrm{N}_{2} \mathrm{O}$ losses and YSNE. As a consequence, the mean values of $\mathrm{N}$ surplus (Table 2) were below the threshold (20-50 $\mathrm{kg} \mathrm{Nha}^{-1}$ ) of an exponential increase of YSNE (van Groenigen et al., 2010). Remarkably, $\mathrm{N}$ surplus was significantly higher in the first campaign, with the driest conditions, in spite of the lower rate of application of synthetic $\mathrm{N}$. This would suggest that there was inefficient uptake of $\mathrm{N}$ uptake under water stress conditions, resulting in very low grain yields, without higher $\mathrm{N}_{2} \mathrm{O}$ losses due to unfavorable soil WFPS, as explained above.

Our results highlight the importance of crop rotation as an effective YSNE mitigation strategy. Concerning the tillage*campaign interaction for YSNE, this was highly influenced by grain yields. 
Overall, NT significantly reduced YSNE as opposed to MT, which had no effect on area-scaled $\mathrm{N}_{2} \mathrm{O}$ losses but was a less advantageous tillage management considering the YSNE ratio. In the campaign with less rainfall than the average, NT mitigated YSNE, as observed by van Kessel et al. (2013) for long-term studies under dry conditions, so it emerges as an interesting option in a global change context with increased aridity. In contrast, in normal rainfall campaigns $\mathrm{CT}$ arises as the most sustainable alternative for increasing grain yields while leading to similar $\mathrm{N}_{2} \mathrm{O}$ losses as NT.

\subsection{Global warming potential}

Almost all treatments (except rotational wheat-NT) had positive GHG-GWP emission values (19-204 $\mathrm{kg} \mathrm{CO}_{2}$-eq ha ${ }^{-1}$ ), showing that in spite of low $\mathrm{N}_{2} \mathrm{O}$ fluxes, $\mathrm{CH}_{4}$ oxidation did not offset $\mathrm{N}_{2} \mathrm{O}$ losses (Fig. 4). As reported by previous studies (e.g. Aguilera et al., 2013a, 2015; Plaza-Bonilla et al., 2015; Abdalla et al., 2015), NT significantly increased the SOC content compared with CT (Table 3). This occurred despite the higher SOC content in the 15-30 cm layer in CT (as opposed to NT/MT), as suggested by Baker et al. (2007). The ' $\triangle S O C$ ' was the main cause of the differences between tillage and crop treatments (Fig. 4), while $\mathrm{CO}_{2}$-eq emissions from inputs and operations were significant but less important, a finding which is consistent with Aguilera et al. (2015) and Guardia et al. (2016). Therefore, our results indicate that management practices which promote an increase in C stocks (e.g. NT) should be recommended in semi-arid areas. Supporting our findings, the recent meta-analysis of Abdalla et al. (2015) pointed out that the abatement of $\mathrm{CO}_{2}$-eq emissions through NT adoption is significantly higher in arid climates with low SOC content, as opposed to CT. Nitrous oxide $\left(\mathrm{N}_{2} \mathrm{O}\right)$ emissions have shown to carry less weight in GWP estimates than in previous studies (Mosier et al., 2006; Adviento-Borbe et al., 2007), but uncertainties associated with SOC accumulation and its calculation (Guardia et al., 2016) and the large climatic variability in rainfed semi-arid cropping areas, suggest that strategies that mitigate $\mathrm{CO}_{2}$-eq from other GWP components $\left(\mathrm{N}_{2} \mathrm{O}\right.$ losses and inputs, e.g. by adjusting $\mathrm{N}$ rates) must be also considered.

Regarding the crop effect, wheat in rotation tended to decrease SOC accumulation and consequently to enhance GWP $(0.05<P<0.10)$. Although the wheat phase of the rotation led to numerically higher $\mathrm{CO}_{2}$-eq than wheat in monoculture, the widespread fallow-cereal-legume-cereal rotations provide further opportunities to mitigate the GWP during the legume (Guardia et al., 2016) and fallow phases, when lower (or zero) fertilizer inputs are applied.

\section{Conclusions}

Our results showed that cumulative $\mathrm{N}_{2} \mathrm{O}$ emissions and YSNE were low in this long-term experiment carried out under rainfed semiarid conditions with adjusted $\mathrm{N}$ inputs. Nitrous oxide emissions were increased in a year when rainfall was near normal in wheat in monoculture, as opposed to rotational wheat, and decreased in a drier than average year in NT, as opposed to MT/CT. Therefore, Conservation Agricultural practices (NT and rotation) resulted in similar or lower $\mathrm{N}_{2} \mathrm{O}$ losses than conventional ones in this semi-arid low $\mathrm{N}$ input system. Grain yield and consequently YSNE were strongly affected by climatic variability, since NT and CT resulted in significantly higher productivities and lower YSNE in the dry and the normal campaigns, respectively. Wheat in rotation significantly mitigated YSNE, as opposed to wheat in monoculture. Higher SOC content caused NT to reduce Net GWP compared with the rest of tillage treatments. No-till should be recommended in semi-arid areas to mitigate the Net GWP of semiarid agro-ecosystems, providing the opportunity to reduce YSNE in dry years and therefore in a global change scenario. By contrast, MT performed less well on the basis of YSNE and GWP balances. Wheat in rotation tended to increase Net GWP, but the abatement of YSNE and the opportunities for reducing input $\mathrm{CO}_{2}$ emissions during other rotation phases (fallow and/or legume) may provide and optimum balance between grain yields and GHG mitigation. Due to the influence of soil and climatic variability, further studies in semi-arid areas are needed to confirm our results.

\section{Acknowledgements}

The authors are grateful to the Spanish Ministry of Economy and Innovation and the Community of Madrid for their economic support through Projects AGL2012-37815-C05-01-AGR and the Agrisost-CM Project (S2013/ABI- 2717). We also thank the technicians and researchers at the Department of Chemistry and Agricultural Analysis of the Agronomy Faculty (Technical University of Madrid, UPM). We offer a special thanks to the field assistants at the "La Canaleja" field station. This work was done in the frame of the Moncloa Campus of International Excellence (UCM-UPM).

\section{References}

Abalos, D., Sanz-Cobena, A., Garcia-Torres, L., van Groenigen, J.W., Vallejo, A., 2013. Role of maize stover incorporation on nitrogen oxide emissions in a non-irrigated Mediterranean barley field. Plant Soil 364 (1-2), 357-371.

Abdalla, K., Chivenge, P., Ciais, P., Chaplot, V., 2015. No-tillage lessens soil $\mathrm{CO}_{2}$ emissions the most under arid and sandy soil conditions: results from a meta-analysis. Biogeosciences 13 (12), 3619-3633.

Adviento-Borbe, M.A.A., Haddix, M.L., Binder, D.L., Walters, D.T., Dobermann, A., 2007. Soil greenhouse gas fluxes and global warming potential in four high-yielding maize systems, Global Change BioL. 13 (9), 1972-1988.

Aguilera, E., Lassaletta, L., Gattinger, A., Gimeno, B.S., 2013a. Managing soil carbon for climate change mitigation and adaptation in Mediterranean cropping systems: a meta-analysis. Agric, Ecosyst. Environ. 168, 25-36.

Aguilera, E., Lassaletta, L., Sanz-Cobena, A., Garnier, J., Vallejo, A., 2013b. The potential of organic fertilizers and water management to reduce $\mathrm{N}_{2} \mathrm{O}$ emissions in Mediterranean climate cropping systems. A review. Agric. Ecosyst. Environ. 164, 32-52.

Aguilera, E., Guzmán, G.I., Alonso, A.M., 2015. Greenhouse gas emissions from conventional and organic cropping systems in Spain. I. Herbaceous crops. Agron, Sustain, Dev, 1-12.

Álvaro-Fuentes, J., Plaza-Bonilla, D., Arrúe, J.L., Lampurlanés, J., Cantero-Martínez. C., 2014. Soil organic carbon storage in a no-tillage chronosequence under Mediterranean conditions. Plant Soil 376 (1-2), 31-41.

Armengot, L., Berner, A., Blanco-Moreno, J.M., Mäder, P., Sans, F.X., 2015. Long-term feasibility of reduced tillage in organic farming. Agron. Sustain. Dev. $35(1), 339-346$

Aronson, E.L., Helliker, B.R., 2010. Methane flux in non-wetland soils in response to nitrogen addition: a meta-analysis. Ecology 91, 3242-3251.

Baggs, E.M., Smales, C.L., Bateman, E.J., 2010. Changing pH shifts the microbial source as well as the magnitude of $\mathrm{N}_{2} \mathrm{O}$ emission from soil. Biol. Fertil. Soils 46 (8), 793-805.

Baker, J.M., Ochsner, T.E., Venterea, R.T., Griffis, T.J., 2007. Tillage and soil carbon sequestration-what do we really know? Agric. Ecosyst. Environ. 118, 1-5.

Ball, B.C., Scott, A., Parker, J.P., 1999. Field $\mathrm{N}_{2} \mathrm{O}, \mathrm{CO}_{2}$ and $\mathrm{CH}_{4}$ fluxes in relation to tillage, compaction and soil quality in Scotland. Soil Tillage Res. 53 (1), 29-39.

Cayuela, M.L., Aguilera, E., Sanz-Cobena, A., Adams, D.C., Abalos, D., Barton, L. Ryals, R., Silver, W.L., Alfaro, M.A., Pappa, V.A., Smith, P., Garnier, J., Billen, G., Bouwman, L., Bondeau, A., Lassaletta, L, 2016. Direct nitrous oxide emissions in Mediterranean climate cropping systems: emission factors based on a meta-analysis of available measurement data. Agric. Ecosyst. Environ., http:// dx.doi.org/10.1016/j.agee.2016.10,006 (in press)

Chan, A.S.K., Parkin, T.B., 2001. Methane oxidation and production activity in soils from natural and agricultural ecosystems, J. Environ, Qual. 30 (6), 1896-1903.

Chatskikh, D., Olesen, J.E., 2007. Soil tillage enhanced $\mathrm{CO}_{2}$ and $\mathrm{N}_{2} \mathrm{O}$ emissions from loamy sand soil under spring barley. Soil Tillage Res. 97 (1), 5-18.

Chen, H., Li, X., Hu, F., Shi, W., 2013. Soil nitrous oxide emissions following crop residue addition: a meta-analysis. Global Change Biol. 19 (10), 2956-2964.

De Vita, P., Di Paolo, E., Fecondo, G., Di Fonzo, N., Pisante, M., 2007. No-tillage and conventional tillage effects on durum wheat yield, grain quality and soil moisture content in southern Italy. Soil Tillage Res. 92 (1), 69-78.

Dendooven, L., Patino-Zúniga, L, Verhulst, N., Luna-Guido, M., Marsch, R., Govaerts, B., 2012. Global warming potential of agricultural systems with contrasting tillage and residue management in the central highlands of Mexico. Agric. Ecosyst, Environ, 152, 50-58.

Dunfield, P., Knowles, R., 1995. Kinetics of inhibition of methane oxidation by nitrate, nitrite, and ammonium in a humisol. Appl. Environ. Microb. 61 , 3129-3135. 
Ellert, B.H., Bettany, J.R., 1995. Calculation of organic matter and nutrients stored in soils under contrasting management regimes. Can. J. Soil Sci. 75 (4), 529-538. Firestone, M.K., Davidson, E.A., 1989. Microbiological basis of $\mathrm{NO}$ and $\mathrm{N}_{2} \mathrm{O}$ production and consumption in soil. In: Andeae, M.O., Schimel, D.S. (E.ds.), Exchange of Trace Gases Between Terrestrial Ecosystems and the Atmosphere. Wiley, Chichester, pp. 7-21.

Gómez-Paccard, C., Hontoria, C., Mariscal-Sancho, I., Pérez, J., León, P., González, P., Espejo, R., 2015. Soil-water relationships in the upper soil layer in a Mediterranean Palexerult as affected by no-tillage under excess water conditions-influence on crop yield. Soil Tillage Res. 146, 303-312.

García-Marco, S., Abalos, D., Espejo, R., Vallejo, A., Mariscal-Sancho, I., 2016, No tillage and liming reduce greenhouse gas emissions from poorly drained agricultural soils in Mediterranean regions. Sci. Total Environ. 566, 512-520.

Grossman, R.B., Reinsch, T.G., 2002.2.1 Bulk density and linear extensibility. In: Methods of Soil Analysis: Part 4 Physical Methods, (methodsofsoilan4)., pp. $201-228$.

Guardia, G., Tellez-Rio, A., García-Marco, S., Martin-Lammerding, D., Tenorio, J.L., Ibáñez, M.Á. Vallejo, A., 2016. Effect of tillage and crop (cereal versus legume) on greenhouse gas emissions and Global Warming Potential in a non-irrigated Mediterranean field. Agric. Ecosyst. Environ. 221, 187-197.

Huang, Y., Zou, J., Zheng, X., Wang, Y., Xu, X., 2004. Nitrous oxide emissions as influenced by amendment of plant residues with different $\mathrm{C}: \mathrm{N}$ ratios. Soil Biol. Biochem. $36(6), 973-981$.

IPCC, 2014. Climate change 2014: synthesis report, In; Pachauri, R.K., Meyer, L,A. (Eds.), Contribution of Working Groups I, II and III to the Fifth Assessment Report of the Intergovernmental Panel on Climate Change [Core Writing Team]. IPCC, Geneva. Switzerland, p, 151.

Kassam, A., Friedrich, T., Derpsch, R., Lahmar, R., Mrabet, R., Basch, G., González-Sánchez, E.J., Serraj, R., 2012. Conservation agriculture in the dry Mediterranean climate. Field Crop. Res. 132, 7-17.

Kimani, S.K., Nandwa, S.M., Mugendi, D.N., Obanyi, S.N., Ojiem, J., Murwira, H.K. Bationo, A, 2003. Principles of integrated soil fertility management. In: Gichuri, M.P., Bationo, A., Bekunda, M.A., Goma, H.C., Mafongoya, P.L., Mugendi, D.N., Murwuira, H.K., Nandwa, S.M., Nyathi, P., Swift, M.J. (Eds.), Soil Fertility Management in Africa: A Regional Perspective. Academy Science Publishers (ASP), Centro Internacional de Agricultura Tropical (CIAT), Tropical Soil Biology and Fertility (TSBF), Nairobi, KE, pp. 51-72.

López-Bellido, R.J., López-Bellido, L., 2001. Efficiency of nitrogen in wheat under Mediterranean conditions: effect of tillage, crop rotation and $\mathrm{N}$ fertilization. Field Crop. Res. 71 (1), 31-46.

Lal, R., 2004. Carbon emission from farm operations. Environ. Int. 30 (7), 981-990.

Le Mer, J., Roger, P., 2001. Production, oxidation, emission and consumption of methane by soils: a review. Eur. I. Soil Biol. 37, 25-50.

Lenka, N.K., Lal, R., 2013. Soil aggregation and greenhouse gas flux after 15 years of wheat straw and fertilizer management in a no-till system. Soil Tillage Res. $126,78-89$

Li, X., Sørensen, P., Olesen, J.E., Petersen, S.O., 2016, Evidence for denitrification as main source of $\mathrm{N}_{2} \mathrm{O}$ emission from residue-amended soil. Soil Biol. Biochem. 92, 153-160.

Linn, D.M., Doran, J.W., 1984. Effect of water-filled pore space on carbon dioxide and nitrous oxide production in tilled and nontilled soils. Soil Sci. Soc. Am. J. $48,1267-1272$.

Malhi, S.S., Lemke, R., 2007. Tillage, crop residue and N fertilizer effects on crop yield nutrient uptake, soil quality and nitrous oxide gas emissions in a second 4-yr rotation cycle. Soil Tillage Res. 96, 269-283.

Martin-Lammerding, D., Hontoria, C., Tenorio, J.L., Walter, I., 2011. Mediterranean dryland farming: effect of tillage practices on selected soil properties. Agron. J. $103,382-389$.

Morell, F.J., Lampurlanés, J., Álvaro-Fuentes, J., Cantero-Martínez, C, 2011. Yield and water use efficiency of barley in a semiarid Mediterranean agroecosystem: long-term effects of tillage and N fertilization. Soil Tillage Res. 117, 76-84.

Mosier, A.R., Halvorson, A.D., Reule, C.A., Liu, X.J., 2006. Net global warming potential and greenhouse gas intensity in irrigated cropping systems in northeastern Colorado. J. Environ. Qual. 35 (4), 1584-1598.

Mutegi, J.K., Munkholm, L.J., Petersen, B.M., Hansen, E.M., Petersen, S.O., 2010. Nitrous oxide emissions and controls as influenced by tillage and crop residue management strategy. Soil Biol. Biochem, 42 (10), 1701-1711.

Nelson, D.W., Sommers, L.E., 1996. Total carbon, organic carbon, and organic matter. In: Sparks, D.L., Page, A.L., Helmke, P.A., Loeppert, R.H., Soltanpour, P.N., Tabatabai, M.A., Johnston, C.T., Sumner, M.E. (Eds.), Methods of Soil Analysis, Part 3 Chemical Methods. ASA-SSSA, Madison, WI, USA, pp. 961-1010.
Pelster, D.E., Larouche, F., Rochette, P., Chantigny, M.H., Allaire, S., Angers, D.A 2011. Nitrogen fertilization but not soil tillage affects nitrous oxide emissions from a clay loam soil under a maize-soybean rotation, Soil Tillage Res. 115, $16-26$.

Pittelkow, C.M., Linquist, B.A., Lundy, M.E., Liang, X., Van Groenigen, K.J., Lee, J., van Gestel, N., Six, J., Venterea, R.J., Van Kessel, C., 2015. When does no-till yield more?: A global meta-analysis. Field Crops Res. 183, 156-168.

Plaza-Bonilla, D., Cantero-Martínez, C., Bareche, J., Arrúe, J.L., Álvaro-Fuentes, J. 2014. Soil carbon dioxide and methane fluxes as affected by tillage and $\mathrm{N}$ fertilization in dryland conditions. Plant Soil 381, 111-130.

Plaza-Bonilla, D., Arrúe, J.L., Cantero-Martínez, C., Fanlo, R., Iglesias, A., Álvaro-Fuentes, J., 2015. Carbon management in dryland agricultural systems. A review. Agron. Sustain. Dev. 35 (4), 1319-1334.

Rees, R.M., Augustin, J., Alberti, G., Ball, B.C., Boeckx, P., Cantarel, A., Castaldi, S., Chirinda, N., Chojnicki, B., Giebels, M., Gordon, H., Grosz, B., Horvath, L., Juszczak, R, Kasimir Klemedtsson Á, Klemedtsson, L., Medinets, S., Machon, A., Mapanda, F., Nyamangara, J., Olesen, J.E., Reay, D.S., Sanchez, L., Sanz-Cobena, A., Smith, K.A., Sowerby, A., Sommer, M., Soussana, J.F., Stenberg, M., Topp, C.F.E., van Cleemput, O, Vallejo, A., Watson, C.A., Wuta, M., 2013. Nitrous oxide emissions from European agriculture-an analysis of variability and drivers of emissions from field experiments. Biogeosciences 10, 2671-2682.

Robertson, G.P., Paul, E.A., Harwood, R.R., 2000. Greenhouse gases in intensive agriculture: contributions of individual gases to the radiative forcing of the atmosphere. Science 289, 1922-1925.

Sanz-Cobena, A., García-Marco, S., Quemada, M., Gabriel, J.L., Almendros, P., Vallejo, A., 2014. Do cover crops enhance $\mathrm{N}_{2} \mathrm{O}, \mathrm{CO}_{2}$ or $\mathrm{CH}_{4}$ emissions from soil in Mediterranean arable systems? Sci. Total Environ. 466, 164-174.

Sanz-Cobena, A., et al., 2016. Strategies for greenhouse gas emissions mitigation in Mediterranean agriculture: a review, Agric. Ecosyst. Environ., http://dx.doi.org/ 10.1016/j.agee.2016.09.038 (Accepted for publication).

Sarkodie-Addo, J., Lee, H.C., Baggs, E.M., 2003. Nit rous oxide emissions after application of inorganic fertilizer and incorporation of green manure residues. Soil Use Manage. 19(4), 331-339.

Six, J., Ogle, S.M., Conant, R.T., Mosier, A.R., Paustian, K., 2004. The potential to mitigate global warming with no-tillage management is only realized when practised in the long term. Global Change Biol. 10, 155-160.

Snyder, C.S., Bruulsema, T.W., Jensen, T,L., Fixen, P.E., 2009. Review of greenhouse gas emissions from crop production systems and fertilizer management effects. Agric Ecosyst, Environ, 133, 247-266.

Soil Survey Staff, 2010. Keys to Soil Taxonomy, 11 th ed. USDA-Natural Resources Conservation Service, Washington.

Stocker, T.F,, Qin, D., Plattner, G.K., Tignor, M., Allen, S.K, Boschung, J., Nauels, A., Xia, Y., Bex, V., Midgley, P.M., 2013. Climate change 2013: the physical science basis. In: Contribution of Working Group I to the Fifth Assessment Report of the Intergovernmental Panel on Climate Change. Cambridge University Press, Cambridge, United Kingdom and New York, NY, USA, pp. 1-1535.

Tellez-Rio, A., García-Marco, S., Navas, M., López-Solanilla, E., Rees, R.M., Tenorio, J.L., Vallejo, A., 2015. Nitrous oxide and methane emissions from a vetch cropping season are changed by long-term tillage practices in a Mediterranean agroecosystem. Biol. Fertil. Soils 51 (1), 77-88.

Triberti, L., Nastri, A., Baldoni, G, 2016, Long-term effects of crop rotation, manure and mineral fertilisation on carbon sequestration and soil fertility. Eur. J. Agron. 74, 47-55.

Ussiri, D., Lal, R., 2012. Soil Emission of Nitrous Oxide and Its Mitigation. Springer Science \& Business Media.

van Groenigen, J.W., Velthof, G.L., Oenema, O., van Groenigen, K.J., van Kessel, C., 2010. Towards an agronomic assessment of $\mathrm{N}_{2} \mathrm{O}$ emissions: a case study for arable crops. Eur. J. Soil Sci. 61,903-913.

van Kessel, C., Venterea, R., Six, J., Adviento-Borbe, M.A., Linquist, B., van Groenigen, K.J., 2013. Climate, duration, and $\mathrm{N}$ placement determine $\mathrm{N}_{2} \mathrm{O}$ emissions in reduced tillage systems: a meta-analysis. Global Change Biol. 19, 33-44.

West, T.O., Marland, G., 2002. A synthesis of carbon sequestration, carbon emissions, and net carbon flux in agriculture: comparing tillage practices in the United States. Agric. Ecosyst. Environ. 91, 217-232

Yonemura, S., Nouchi, I., Nishimura, S., Sakurai, G., Togami, K., Yagi, K., 2014. Soil respiration, $\mathrm{N}_{2} \mathrm{O}$, and $\mathrm{CH}_{4}$ emissions from an Andisol under conventional-tillage and no-tillage cultivation for 4 years. Biol. Fertil. Soils 50 (1), 63-74. 